\title{
PENGEMBANGAN APLIKASI SAKPORE DI SMK NEGERI 2 PEKALONGAN
}

\author{
UNTUNG SUPRIYONO \\ SMK Negeri 2 Pekalongan \\ e-mail: itsmartz79@gmail.com
}

\begin{abstract}
ABSTRAK
Sakpore adalah Sistem Aplikasi Kewirausahaan Prospektif dengan Orientasi Revolusi 4.0, sakpore merupakan startup sekaligus wahana pembelajaran peserta didik berupa perniagaan daring yang bergerak dibidang kuliner, jejamu dan keperluan rumah tangga di SMK Negeri 2 Pekalongan. Tujuan penelitian ini adalah untuk mengembangkan Sistem Aplikasi Kewirausahaan Prospektif dengan Orientasi Revolusi 4.0 (Sakpore) guna Meningkatkan Hasil Belajar dan Minat Wirausaha Peserta Didik Kelas XI PSPT SMK Negeri 2 Pekalongan pada materi Produk Kreatif dan Kewirausahaan. Penelitian pengembangan ini menggunakan model 4D yang terdiri dari Define, Design, Develop, dan Disseminate. Kevalidan Aplikasi SAKPORE dilakukan oleh ahli media, ahli materi dan pengguna yaitu guru dan peserta didik, diperoleh skor rata-rata 54,00 dan masuk dalam kategori sangat layak. Keefektifan media pembelajaran dilakukan dengan membandingkan hasil belajar pretest dan posttest aspek keterampilan pada Pembelajaran Produk Kreatif dan Kewirausahaan. Hasil Belajar mengalami peningkatan baik pada uji terbatas dan uji luas, yaitu dari rata-rata 73.37 menjadi rata-rata 80.68 , sehingga dapat disimpulkan Aplikasi Sakpore berbasis Android sangat layak dan efektif meningkatkan hasil belajar peserta didik mata pelajaran Prakarya dan Kewirausahaan.
\end{abstract}

Kata Kunci : Aplikasi, Sakpore, Produk Kreatif, Kewirausahaan

\section{PENDAHULUAN}

Revolusi Industri keempat mengubah cara berinteraksi dengan bisnis (Savitri, 2019), perangkat seluler yang dilengkapi internet memungkinkan kita untuk menemukan informasi tentang produk dan layanan kapan saja. Hal ini membawa cakrawala baru, memberikan harapan sekaligus tantangan bagi dunia pendidikan. Maraknya informasi melalui media sosial sebagai dampak dari globalisasi sangat berperan dalam berkembangnya interaksi dan konektifitas. Ada kemajuan, kemudahan namun persaingan menjadi semakin meningkat, utamanya persaingan dunia kerja. Kita dihadapkan dengan kenyataan akan tingginya angka pengangguran akibat penawaran tenaga kerja yang sangat tinggi sedangkan permintaannya relatif rendah.

Setiap tahun angka pengangguran di Indonesia cenderung mengalami peningkatan. Berdasarkan data Badan Pusat Statistik (BPS) Tingkat Pengangguran Terbuka (TPT) Februari 2016 sebesar 7,02 juta orang atau 5,5\%. Pada Bulan Februari Tahun 2016, TPT untuk pendidikan Sekolah Menengah Kejuruan (SMK) menempati posisi tertinggi yaitu sebesar 9,84 persen (Sussi Widiastuti, 2018). Kondisi ini menyebabkan pekerjaan rumah sekaligus tantangan Sekolah Menengah Kejuruan (SMK) semakin besar.

Sejak Tahun 2017 telah diterapkan Program Revitalisasi Vokasi yang merombak pendekatan cara belajar di SMK mulai dari teknologi sampai ke pengembangan karakter dan keterampilan lunak (Kompas, 2019). Otomasi sebagai bawaan dari perkembangan teknologi digital merupakan keniscayaan. SMK harus lekat dengan dinamika yang terjadi di dunia usaha dan industri, jejaring internet dan kecerdasan buatan merupakan potensi baru yang harus dikuasai dan dikembangkan, SMK wajib membekali peserta didik untuk bisa bekerja secara mandiri dan terampil. Keterampilan yang diberikan tidak hanya sekedar keterampilan, tetapi bernilai holistik dan berhasil menerapkan keterampilan dalam kegiatan bisnis yang produktif (Pradani, 2017). Jadi Sekolah wajib memberikan pembelajaran kewirausahaan bagi peserta didik baik dalam kegiatan produksi maupun manajemen pemasaran, sehingga peserta didik memiliki keterampilan yang dapat digunakan dalam kehidupan masyarakat dan dunia kerja. 
Perangkat dan aplikasi seluler mengubah cara seseorang dalam mengumpulkan, memproses, dan berbagi informasi (Silvius, 2015). Maka penggunaan perangkat tersebut dalam pemelajaran adalah tindakan yang efektif. Model pembelajaran kewirausahaan yang efektif dapat menghantarkan peserta didik untuk menjadi seorang entrepreneur secara mandiri (Jaedun, 2015). Seorang entrepreneur sering digambarkan sebagai seseorang yang visioner dan bersemangat dengan pekerjaan mereka, serta merasakan hubungan yang mendalam dengan produk sekaligus layanan yang mereka buat (Wiklund, 2019). Tindakan wirausaha dipahami sebagai tindakan inovatif melalui sistem hubungan manusia yang terorganisir dan kombinasi sumber daya, serta diarahkan menuju pencapaian tujuan tertentu (Barba-Sánchez, 2018). Prinsipnya, Pendidikan kewirausahaan di era revolusi 4.0 diarahkan untuk menciptakan entrepreneur yang inovatif dan kreatif. Jika mencermati kompetensi inti dan kompetensi dasar mata pelajaran Produk Kreatif dan Kewirausahaan Kurikulum 2013, pendidikan lebih ditekankan pada prakarya semata. Prakarya yang dipelajari di jenjang pendidikan menengah meliputi kerajinan, rekayasa, budidaya, dan pengolahan. Sistem pendidikan yang dibangun berorientasi pada peningkatan tamatan yang benar - benar profesional, memiliki etos kerja, disiplin dan tetap menjunjung tinggi serta berakar pada budaya bangsa.

Mencermati dari beberapa permasalahan yang penulis uraikan di atas, upaya pengembangan aktivitas, kreativitas, dan motivasi peserta didik didalam proses pembelajaran sangatlah penting, diperlukan adanya inovasi dan strategi pembelajaran yang mencakup pendekatan pembelajaran, metode pembelajaran, dan sumber belajar yang digunakan. Strategi yang dipilih selain yang berpotensi merangsang peserta didik belajar secara aktif, juga harus mampu memberi kemudahan atau menjadi fasilitas belajar bagi peserta didik sehingga dihasilkan pembelajaran yang bermakna. Untuk keperluan tersebut guru mengarahkan perhatian peserta didik melalui aktivitas pembelajaran yang menyenangkan dan mempunyai potensi yang tinggi (prospektif), dalam arti isi pelajaran dan konsep diterjemahkan secara jelas dalam media pembelajaran digital yang dapat diakses kapanpun. Media yang digunakan harus dapat mempengaruhi intelek, emosi, dan minat belajar. Kedudukan media pembelajaran digital ada dalam komponen mengajar sebagai salah satu upaya untuk mempertinggi proses interaksi guru dengan peserta didik serta mempermudah interaksi peserta didik dengan lingkungan belajarnya. Pembelajaran Digital dengan memanfaatkan Aplikasi merupakan satu alternatif yang dapat dijadikan sebagai pembelajaran yang menyenangkan.

Berdasarkan pengalaman penulis mengajar di SMK Negeri 2 Pekalongan, kolaborasi beberapa metode pengajaran Produk Kreatif dan Kewirausahaan merupakan pilihan yang paling tepat dalam upaya mengembangkan aktivitas, kreatifitas, dan motivasi peserta didik. Oleh karena itu penulis mengembangkan Sistem Aplikasi Kewirausahaan Prospektif dengan Orientasi Revolusi 4.0 (SAKPORE) untuk Meningkatkan Minat Wirausaha Peserta Didik Kelas XI PSPT SMK Negeri 2 Pekalongan Pada Materi Produk Kreatif dan Kewirausahaan. Hal tersebut untuk memberi pembelajaran yang bermakna dan dapat bertahan lama. Pada satu sisi, Peserta Didik menjadi cinta terhadap materi pelajaran Produk Kreatif dan Kewirausahaan.

\section{METODE PENELITIAN}

Metode yang digunakan dalam penelitian ini adalah metode penelitian dan pengembangan atau Research and Development. Pengembangan atau Research and Development adalah metode penelitian yang digunakan untuk menghasilkan produk tertentu dan menguji keefektifan produk tersebut.

Untuk dapat menghasilkan produk tertentu digunakan penelitian yang bersifat analisis kebutuhan dan untuk menguji kefektifan produk tersebut supaya dapat berfungsi di masyarakat luas, maka diperlukan penelitian untuk menguji keefektifan produk tersebut.

Model penelitian pengembangan yang digunakan mengikuti alur dari Thiagarajan (1974). Model pengembangan 4-D terdiri dari 4 tahap yaitu Define, Design, Develop, dan Disseminate atau diadaptasikan menjadi model 4-P, yaitu Pendefinisian, Perancangan, 
Pengembangan, dan Penyebaran. Model 4-D inilah yang digunakan dalam penelitian ini dan disesuaikan dengan kebutuhan pengembangan di lapangan.

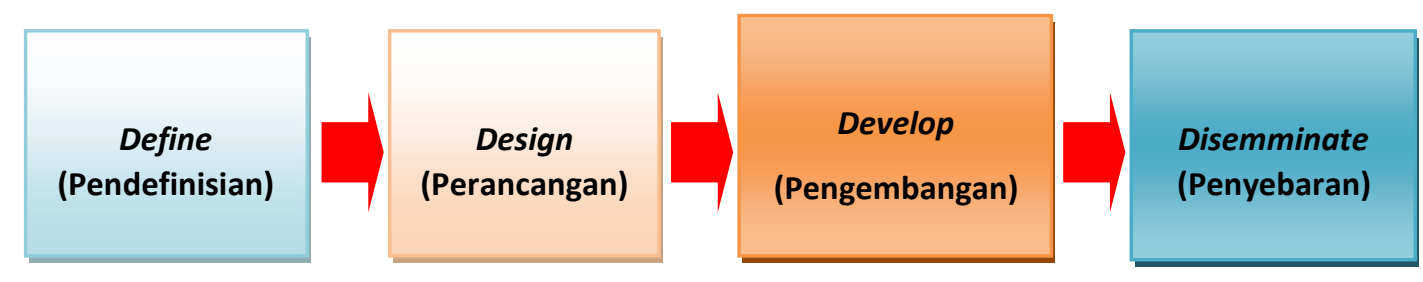

Gambar 1. Alur model pengembangan 4-D Thiagarajan

\section{Tahap Pendefinisian (define)}

Pendefinisian diantaranya untuk menetapkan dan mendefinisikan kebutuhan di dalam proses pembelajaran. Kebutuhan-kebutuhan yang diperlukan agar proses pembelajaran dapat berjalan dengan baik dan proses penilaian dapat lebif efektif. Dalam hal ini penelitian melakukan penelitian pendahuluan dengan melakukan wawancara terhadap peserta didik SMK Negeri 2 Pekalongan sebagai langkah observasi.

\section{Tahap Perancangan (design)}

Tujuan dari tahap perancangan yaitu Sistem Aplikasi Kewirausahaan Prospektif dengan Orientasi Revolusi 4.0 (SAKPORE) yang digunakan dalam Pembelajaran Prakraya Kewirausahaan. Dalam tahap ini mulai dirancang bentuk media media, instrumen analisis kebutuhan, instrumen observasi penggunaan aplikasi, dan instrumen evaluasi (pretes dan post tes). Berdasar analisis kebutuhan dan tujuan pembelajaran, ada tiga tahap yang di tempuh, yaitu: (1) perencanaan materi sesuai tujuan pembelajaran, (2) perencanaan desain media dan (3) pembuatan aplikasi. Berdasarkan masukan dari hasil validasi ahli dan pengguna, produk berupa aplikasi Sakpore direvisi sesuai saran dari validator

\section{Tahap Pengembangan (develop)}

Pada tahap ini produk yang sudah direvisi berdasarkan saran dari validator yang terdiri dari ahli dan pengguna, selanjutkan dilakukan uji coba terbatas. Uji coba terbatas dilakukan pada 1(satu) kelompok dalam hal ini satu kelas yaitu kelas XI PSPT. Uji coba terbatas dilakukan pada pembelajaran tahun pelajaran 2019/2020.

\section{Tahap Penyebaran (disseminate)}

Pada tahap ini produk hasil uji coba terbatas direvisi sesuai dengan masukan pada uji coba terbatas, kemudian dilakukan uji coba luas /uji lapangan di kelas pada skala yang lebih besar. Uji coba lapangan dilaksanakan pada kelas X PSPT, XI PSPT dan XI BDPM. Sebagai penyebaran lebih luas lagi pada tahun pelajaran 2019/2020 dilakukan tahap penyebaran lebih luas yaitu peserta didik SMK yang ada di Pekalongan melalui guru yang tergabung dalam wadah Musyawarah Guru Mata Pelajaran (MGMP) Produk Kreatif dan Kewirausahaan Kota Pekalongan. Uji coba produk yang sesungguhnya dilaksanakan untuk mengetahui efektivitas media yang dikembangkan dengan menggunakan produk berupa Aplikasi Sakpore. Prosedur penelitian dengan model 4D dapat digambarkan sebagai berikut:

\section{Subyek Penelitian}

Penelitian ini dilaksanakan di SMK Negeri 2 Pekalongan. Subyeknya adalah peserta didik kelas XI TP3RP pada ujicoba terbatas dan X PSPT, XI PSPT dan XI BDPM pada ujicoba luas. Uji coba lapangan dilakukan pada Semester gasal tahun ajaran 2019/2020. Subyek uji coba lapangan ini adalah peserta didik kelas XI PSPT. 
Tabel 1. Subyek Penelitian

\begin{tabular}{|c|c|c|}
\hline No & Kelas & Jumlah peserta didik \\
\hline 1 & X PSPT & 32 \\
\hline 2 & XI PSPT & 32 \\
\hline 3 & XI BDPM & 32 \\
\hline \multicolumn{2}{|r|}{ Jumlah } & 96 \\
\hline
\end{tabular}

\section{Instrument Pengumpulan Data}

Instrumen yang digunakan dalam pengumpulan data pada pengembangan ini berupa angket. Angket ini ditujukan untuk subyek uji coba. Adapun angket yang dibutuhkan adalah: Angket Penilaian Ahli Materi, Angket Penilaian Ahli Desain Pembelajaran, Angket Penilaian Ahli Bahasa, Angket Penilaian Ahli Pembelajaran/ Guru SMK Negeri 2 Pekalongan, dan Angket Penilaian Peserta Didik Uji Coba Lapangan.

Tujuan penggunaan angket ini adalah untuk memperoleh data penelitian demi kesempurnaan dan kelayakan produk hasil pengembangan. Selain itu, juga menggunakan test uji beda untuk melihat peningkatan hasil belajar peserta didik dari pre-test ke post-test. Tes pencapaian hasil belajar yang digunakan untuk mengukur pencapaian seseorang setelah mempelajari sesuatu. Tes digunakan untuk memperoleh hasil pre-test dan post-test yang menunjukkan keefektifan belajar peserta didik setelah menggunakan bahan ajar.

\section{Teknik dan Instrumen Pengumpulan Data}

Instrumen penelitian adalah alat atau fasilitas yang digunakan oleh peneliti dalam mengumpulkan data agar pekerjaannya lebih mudah dan hasilnya lebih baik, dalam arti lebih cermat, lengkap, dan sistematis sehingga lebih mudah diolah. Teknik pengumpulan data yang digunakan dalam penelitian ini adalah: (1) wawancara , (2) angket, (3) dokumentasi, dan (4) tes.

Tabel 2. Instrumen aspek pengguna/ peserta didik

\begin{tabular}{|c|l|l|c|}
\hline No. & \multicolumn{1}{|c|}{ Aspek } & \multicolumn{1}{|c|}{ No butir pertanyaan } & Jumlah butir \\
\hline 1 & Aspek Materi & $1,2,3,4,5$ & 5 \\
\hline 2 & Aspek Kelengkapan & $6,7,8,9,10$ & 5 \\
\hline 3 & Aspek Rekayasa & $11,12,13,14,15$ & 5 \\
\hline & Jumlah butir pertanyaan & 15 \\
\hline
\end{tabular}

\section{HASIL DAN PEMBAHASAN}

\section{Penggunaan Media saat ini}

Hasil penelitian pendahuluan yang dilakukan peneliti dengan wawancara pada peserta didik Kompetensi Keahlian Produksi dan Siaran Program Televisi (PSPT), diperoleh hasil untuk saat ini sebagian besar guru belum menggunakan aplikasi berbasis Android. Kegiatan pembelajaran berbasis TIK umumnya menggunakan slide powerpoint yang selama ini digunakan guru dan banyak menggunakan kertas (modul, lks, buku pengayaan dlsb) namun ada beberapa yang menggunakan e-Modul.

\section{Desain Media}

Draft desain media dibuat berdasarkan studi pendahuluan dan hasil penelitian pendahuluan. Aplikasi SAKPORE untuk pembelajaran Produk Kreatif dan Kewirausahaan. 


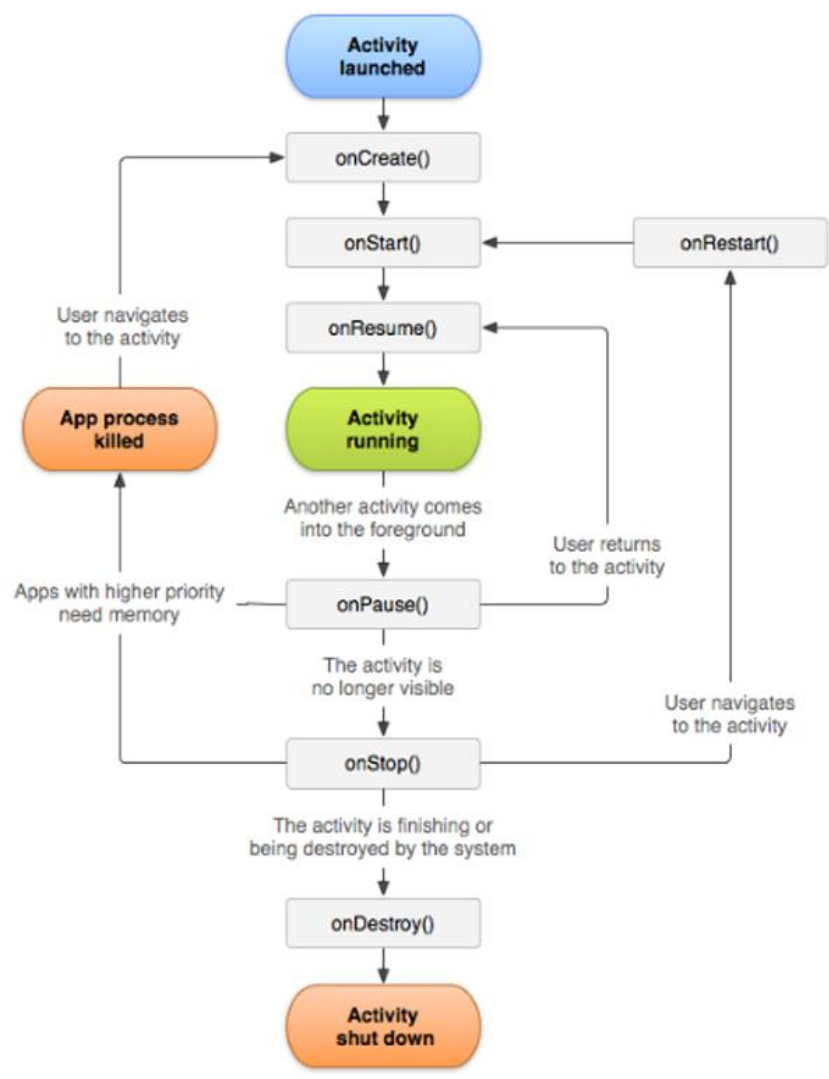

\section{Gambar 2. Desain Media}

\section{Validasi Aplikasi Sakpore}

Dari draft desain media yang dibuat berdasarkan penelitian pendahuluan dan analisis kebutuhan sebelum diujicobakan dalam uji coba terbatas terlebih dahulu divalidasi oleh ahli materi, ahli media dan pengguna dalam hal ini guru. Penilaian peroleh dengan cara menyajikan desain media penilaian Aplikasi dilengkapi dengan instrumen validasi. Setelah penilaian diperoleh, dilanjutkan dengan analisis dengan analisis skor yang diperoleh tiap-tiap butir penilaian. Besarnya skor diklasifikasi dengan kategori berikut.

Tabel 3. Penilaian Aplikasi oleh Ahli dan Pengguna

\begin{tabular}{|c|c|c|}
\hline Skor perolehan & Kategori & Keterangan \\
\hline $48,75-60,00$ & Sangat baik & Dapat dipakai tanpa revisi \\
\hline $37,50-48,75$ & Baik & Dapat dipakai dengan sedikit revisi \\
\hline $26,50-37,50$ & Cukup & Dapat dipakai dengan banyak revisi \\
\hline $15,00-26,50$ & Kurang & Tidak dapat digunakan \\
\hline
\end{tabular}

Hasil skor perolehan penilaian dari ahli dan pengguna tersebut dapat diketahui apakah media penilaian Aplikasi dapat digunakan untuk uji terbatas. Apabila hasil validasi ahli dan pengguna masih berkategori cukup, atau kurang, berarti media penilaian Aplikasi diperbaiki sesuai saran penilai dari aspek-aspek yang belum baik.

Penilaian ahli dan pengguna Danang Subagiyo, S.Kom dan Yusuf Febrianto, S.Kom, M.Kom, terhadap Aplikasi diperoleh skor rata-rata 54,00. Oleh karena itu, jika ditinjau dengan tabel 4.1, dalam skala skor 48,75 - 60 validasi media penilaian Aplikasi dinyatakan berkategori sangat baik, dan dapat digunakan untuk uji coba. 
Aplikasi Sakpore hasil validasi ahli dan pengguna diperbaiki sesuai dengan saran dari ahli dan pengguna untuk selanjutnya digunakan sebagai media pembelajaran dalam uji coba terbatas dan proses pembelajaran. Saran dan perbaikan media penilaian Aplikasi sebagai berikut:

Tabel 4. Saran dan perbaikan Aplikasi Sakpore

\begin{tabular}{|c|c|c|}
\hline Validator & Saran/masukan & Perbaikan \\
\hline Ahli Materi & Jumlah materi diperbanyak serta & diberi \\
& $\begin{array}{c}\text { Nilai yang tersimpan dalam } \\
\text { database }\end{array}$ & $\begin{array}{c}\text { Materi sudah diperbanyak sesuai saran } \\
\text { Nilai sudah bisa tersimpan } \\
\text { dalam database }\end{array}$ \\
\hline Ahli Media & $\begin{array}{c}\text { Belum bisa berpindah Posisi } \\
\text { landscape dan portrait } \\
\text { Warna kurang kontras }\end{array}$ & $\begin{array}{c}\text { Sudah bisa berpindah posisi } \\
\text { landscape dan portrait } \\
\text { Warna sudah dibuat lebih kontras }\end{array}$ \\
\hline Pengguna & Ditambahkan pewaktu \\
& Ditambahkan skroing dan \\
& rangking & Pewaktu sudah ditambahkan \\
& & Skoring dan rangking sudah ditambahkan \\
\hline
\end{tabular}

Media penilaian Aplikasi diperbaiki berdasarkan saran dan perbaikan dari tim Ahli dan pengguna. Hasil perbaikan media penilaian Aplikasi digunakan dalam uji coba terbatas.

\section{Uji Coba Media Aplikasi Sakpore}

1) Uji CobaTerbatas

Analisis observasi terhadap penggunaan Aplikasi Sakpore, Penyajian data terhadap observasi penggunaan Aplikasi, dalam bentuk tabel distribusi frekuensi.

Tabel 5. Aspek manfaat pada Uji Coba Terbatas

\begin{tabular}{ccccc}
\hline No & Interval & Frekuensi & Prosentase (\%) & Kategori \\
\hline 1. & $4-8$ & 0 & 0 & Tidak Setuju \\
2. & $9-12$ & 0 & 0 & Kurang setuju \\
3. & $13-16$ & 10 & 28,6 & Setuju \\
4. & $17-20$ & 25 & 71,4 & Sangat Setuju \\
\hline & Total & 35 & 100.0 & \\
\hline
\end{tabular}

Dari tabel 5 Aspek Manfaat Aplikasi prosentase terbesar pada kategori sangat setuju. Deskripsi tentang aspek manfaat media diperoleh melalui prosedur frekuensi dalam program SPSS 16 yang dilakukan terhadap 32 peserta didik. Hasil perhitungan diketahui bahwa nilai mean $=17,1143 ;$ median $=17,0 ;$ standar deviasi $=1,10537$; variance $=1,222 ;$ range $=5$; terendah $=15$ dan tertinggi $=20$.

Tabel 6. Aspek kelengkapan pada Uji Coba Terbatas

\begin{tabular}{ccccc}
\hline No & Interval & Frekuensi & Prosentase (\%) & Kategori \\
\hline 1. & $4-8$ & 0 & 0 & Tidak Setuju \\
2. & $9-12$ & 0 & 0 & Kurang setuju \\
3. & $13-16$ & 10 & 28,6 & Setuju \\
4. & $17-20$ & 25 & 71,4 & Sangat Setuju \\
\hline & Total & 35 & 100.0 & \\
\hline
\end{tabular}


Dari tabel 6 Aspek kelengkapan Aplikasi prosentase terbesar pada kategori sangat setuju. Deskripsi tentang aspek manfaat media diperoleh melalui prosedur frekuensi dalam program SPSS 16 yang dilakukan terhadap 32 peserta didik. Hasil perhitungan diketahui bahwa nilai mean $=17,1143 ;$ median $=17,0 ;$ standar deviasi $=1,75039$; variance $=3,064 ;$ range $=7$; terendah $=13$ dan tertinggi $=20$.

Tabel 7. Aspek Rekayasa pada Uji Coba Terbatas

\begin{tabular}{ccccc}
\hline No & Interval & Frekuensi & Prosentase (\%) & Kategori \\
\hline 1. & $4-8$ & 0 & 0 & Tidak Setuju \\
2. & $9-12$ & 0 & 0 & Kurang setuju \\
3. & $13-16$ & 12 & 34,3 & Setuju \\
4. & $17-20$ & 23 & 65,7 & Sangat Setuju \\
\hline & Total & 35 & 100.0 & \\
\hline
\end{tabular}

Dari tabel 7 Aspek Rekayasa Media Penilaian Aplikasi prosentase terbesar pada kategori sangat setuju. Deskripsi tentang aspek rekayasa media diperoleh melalui prosedur frekuensi dalam program SPSS 16 yang dilakukan terhadap 32 peserta didik. Hasil perhitungan diketahui bahwa nilai mean $=17,0286 ;$ median $=17,0 ;$ standar deviasi $=1,42428 ;$ variance $=2,029 ;$ range $=6$; terendah $=14$ dan tertinggi $=20$.

\section{2) Analisis pretest dan posttest Peserta Didik}

Uji coba terbatas dilakukan pada Peserta Didik Kompetensi Kejuruan Produksi dan Siaran Program Televisi kelas XI sejumlah 32 peserta didik. Untuk mengetahui tingkat ketepatan Aplikasi dilihat dari ketercapaian tujuan dengan analisis hasil peningkatan hasil belajar peserta didik dengan uji t yaitu untuk membandingkan selisih dua mean dari nilai pretest dan posttest pada mata pelajaran Produk Kreatif dan Kewirausahaan.

Tabel 8. Hasil uji Paired Samples Tes pada uji coba terbatasPaired Samples Statistics

\begin{tabular}{|rr|c|c|c|c|}
\hline & Mean & N & Std. Deviation & Std. Error Mean \\
\hline Pair 1 & pre_test & 73.97 & 35 & 4.211 & .712 \\
& & & & \\
& post_test & 80.03 & 35 & 2.411 & .408 \\
\hline
\end{tabular}

Paired Samples Correlations

\begin{tabular}{|c|c|c|c|}
\hline & $\mathrm{N}$ & Correlation & Sig. \\
\hline Pair 1 pre_test \& post_test & 35 & .231 & .182 \\
\hline
\end{tabular}

Paired Samples Test

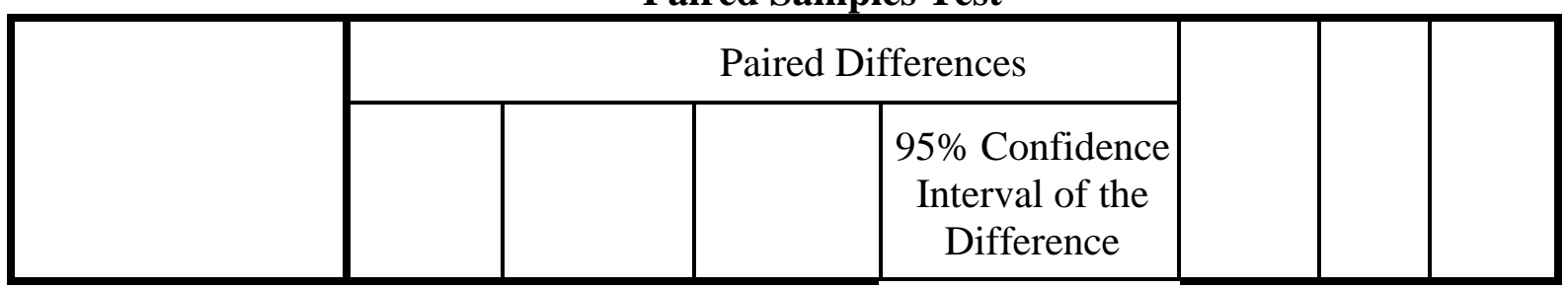




\begin{tabular}{|c|c|c|c|c|c|c|c|c|}
\hline & Mean & $\begin{array}{c}\text { Std. } \\
\text { Deviation }\end{array}$ & $\begin{array}{c}\text { Std. Error } \\
\text { Mean }\end{array}$ & Lower & Upper & $\mathrm{t}$ & df & $\begin{array}{c}\text { Sig. } \\
(2- \\
\text { tailed })\end{array}$ \\
\hline $\begin{array}{ll}\text { Pair } 1 \text { pre_test - } \\
\text { post_test }\end{array}$ & -6.057 & 4.343 & .734 & -7.549 & -4.565 & -8.252 & 34 & .000 \\
\hline
\end{tabular}

Dengan menggunakan Paired Samples Tes dapat diketahui bahwa perbedaan skor antara skor pretes dan posttes adalah -6,057 dimana rata-rata skor pretest adalah 73,97 dan ratarata skor posttest adalah 80,03. Standar deviasi pretes adalah 4,211 dan standar deviasi post tes 2,411 . Nilai minimum pretes adalah 60 dan nilai maksimum pretes adalah 80 . Nilai minimum posttes adalah 77 dan nilai maksimum posttes 87 .

Nilai $\mathbf{t}$ hitung didapat $-8,252$ dengan signifikansi $\mathrm{p}=0,000$ atau $(\mathrm{p}<0,05)$, yang berarti $\mathrm{H} 0$ ditolak dan H1 diterima, sehingga dapat disimpulkan bahwa ada perbedaan rata-rata antara skor pretes dan skor posttes pada mata pelajaran Produk Kreatif dan Kewirausahaan dengan menggunakan Aplikasi pada saat melaksanakan evaluasi.

\section{3) Uji Coba Luas}

Analisis observasi terhadap penggunaan Aplikasi Sakpore. Penyajian data terhadap observasi penggunaan Aplikasi Sakpore, pada uji coba luas pertama disajikan dalam bentuk tabel distribusi frekuensi.

Tabel 9. Aspek Manfaat pada Uji Coba Luas

\begin{tabular}{ccccccccc}
\hline No & Interval & \multicolumn{2}{c}{ X PSPT } & \multicolumn{2}{c}{ XI PSPT } & XI BDPM & \multirow{2}{*}{ Kategori } \\
\cline { 3 - 7 } & & Frek & $\mathbf{( \% )}$ & Frek & $\mathbf{( \% )}$ & Frek & $\mathbf{( \% )}$ & \\
\hline 1. & $4-8$ & 0 & 0 & 0 & 0 & 0 & 0 & Tidak setju \\
2. & $9-12$ & 0 & 0 & 0 & 0 & 0 & 0 & Kurang setuju \\
3. & $13-16$ & 11 & 31,4 & 10 & 28,6 & 17 & 48,6 & Setuju \\
4. & $17-20$ & 24 & 68,6 & 25 & 71,4 & 18 & 51,4 & Sangat Setuju \\
\hline & Total & 35 & 100.0 & 35 & 100.0 & 35 & 100.0 & \\
\hline
\end{tabular}

Dari tabel 9 Aspek Manfaat Media Penilaian Aplikasi prosentase terbesar pada kategori sangat setuju. Deskripsi tentang aspek manfaat media diperoleh melalui prosedur frekuensi dalam program SPSS didapat hasil sebagai berikut.

Tabel 10. Deskripsi tentang aspek manfaat media

\begin{tabular}{|c|c|c|c|c|c|c|c|}
\hline Kelas & mean & median & SD & variance & range & min & max \\
\hline X PSPT & 17 & 17 & 1.62698 & 2.647 & 7 & 13 & 20 \\
\hline XI PSPT & 17.1143 & 17 & 1.10737 & 1.222 & 5 & 15 & 20 \\
\hline XI BDPM & 16.6571 & 17 & 1.21129 & 1.467 & 6 & 14 & 20 \\
\hline
\end{tabular}


Tabel 11. Aspek kelengkapan pada Uji Coba Luas

\begin{tabular}{ccccccccc}
\hline \multirow{2}{*}{ No } & Interval & \multicolumn{2}{c}{ X PSPT } & \multicolumn{2}{c}{ XI PSPT } & \multicolumn{2}{c}{ XI BDPM } & Kategori \\
\cline { 3 - 7 } & & Frek & $\mathbf{( \% )}$ & Frek & $\mathbf{( \% )}$ & Frek & $\mathbf{( \% )}$ & \\
\hline 1. & $4-8$ & 0 & 0 & 0 & 0 & 0 & 0 & Tidak setju \\
2. & $9-12$ & 0 & 0 & 0 & 0 & 1 & 2,9 & Kurang setuju \\
3. & $13-16$ & 10 & 28,6 & 12 & 34,3 & 9 & 25,7 & Setuju \\
4. & $17-20$ & 25 & 71,4 & 23 & 65,7 & 25 & 71,4 & Sangat Setuju \\
\hline & Total & 35 & 100.0 & 35 & 100.0 & 35 & 100.0 & \\
\hline
\end{tabular}

Dari tabel 11 Aspek kelengkapan Media Penilaian Aplikasi prosentase terbesar pada kategori sangat setuju. Deskripsi tentang aspek kelengkapan media Penilaian Aplikasi diperoleh melalui prosedur frekuensi dalam program SPSS didapat hasil sebagai berikut.

Tabel 12. Hasil Observasi Aspek kelengkapan

\begin{tabular}{|c|c|c|c|c|c|c|c|}
\hline Kelas & mean & median & SD & variance & range & min & max \\
\hline X PSPT & 17.0286 & 17 & 1.29446 & 1.676 & 5 & 14 & 19 \\
\hline XI PSPT & 17 & 17 & 1.69775 & 2.882 & 7 & 13 & 20 \\
\hline XI BDPM & 17.2 & 17 & 1.93725 & 3.753 & 8 & 12 & 20 \\
\hline
\end{tabular}

Tabel 13. Aspek Rekayasa pada Uji Coba Luas

\begin{tabular}{|c|c|c|c|c|c|c|c|c|}
\hline \multirow[t]{2}{*}{ No } & \multirow[t]{2}{*}{ Interval } & \multicolumn{2}{|c|}{ X PSPT } & \multicolumn{2}{|c|}{ XI PSPT } & \multicolumn{2}{|c|}{ XI BDPM } & \multirow[t]{2}{*}{ Kategori } \\
\hline & & Frek & $(\%)$ & Frek & $(\%)$ & Frek & $(\%)$ & \\
\hline 1. & $4-8$ & 0 & 0 & 0 & 0 & 0 & 0 & Tidak setju \\
\hline 2. & $9-12$ & 0 & 0 & 0 & 0 & 0 & 0 & Kurang setuju \\
\hline 3. & $13-16$ & 15 & 42.9 & 11 & 31.4 & 19 & 54.3 & Setuju \\
\hline 4. & $17-20$ & 20 & 57.1 & 24 & 68.6 & 16 & 45.7 & Sangat Setuju \\
\hline & Total & 35 & 100.0 & 35 & 100.0 & 35 & 100.0 & \\
\hline
\end{tabular}

Dari tabel 13 Aspek rekayasa Aplikasi prosentase terbesar pada kategori sangat setuju. Deskripsi tentang aspek rekayasa media Penilaian Aplikasidiperoleh melalui prosedur frekuensi dalam program SPSS didapat hasil sebagai berikut.

Tabel 14. Hasil Observasi Aspek rekayasa Aplikasi

\begin{tabular}{|c|c|c|c|c|c|c|c|}
\hline Kelas & mean & median & SD & variance & range & minimum & maximum \\
\hline X PSPT & 16.7714 & 17 & 1.55461 & 2.417 & 6 & 13 & 19 \\
\hline XI PSPT & 17.0857 & 17 & 1.50238 & 2.257 & 6 & 14 & 20 \\
\hline $\begin{array}{c}\text { XI } \\
\text { BDPM }\end{array}$ & 16.5714 & 16 & 1.09237 & 1.193 & 5 & 15 & 20 \\
\hline
\end{tabular}

4) Analisis pretest dan posttest peserta didik

Untuk mengetahui tingkat ketepatan Aplikasi dilihat dari ketercapaian tujuan dengan analisis hasil peningkatan hasil belajar peserta didik dengan uji t yaitu untuk membandingkan selisih dua mean dari nilai pretest dan posttest pada mata pelajaran Produk Kreatif dan Kewirausahaan. 
Tabel 15. Analisis Pretest Posttest

\begin{tabular}{|c|c|c|c|c|c|c|c|c|}
\hline & \multicolumn{5}{|c|}{ Paired Differences } & \multirow[b]{3}{*}{$\mathrm{t}$} & \multirow[b]{3}{*}{$\mathrm{df}$} & \\
\hline & \multirow[b]{2}{*}{ Mean } & \multirow{2}{*}{$\begin{array}{c}\text { Std. } \\
\text { Deviation }\end{array}$} & \multirow{2}{*}{$\begin{array}{l}\text { Std. } \\
\text { Error } \\
\text { Mean }\end{array}$} & \multicolumn{2}{|c|}{$\begin{array}{c}95 \% \text { Confidence } \\
\text { Interval of the } \\
\text { Difference }\end{array}$} & & & \\
\hline & & & & Lower & Upper & & & $\begin{array}{l}\text { Sig. (2- } \\
\text { tailed) }\end{array}$ \\
\hline $\begin{aligned} \text { Pair } 1 \text { pre_test - } & \\
& \text { post_test }\end{aligned}$ & -6.276 & 5.123 & .500 & -7.268 & -5.285 & -12.555 & 104 & .000 \\
\hline
\end{tabular}

Paired Samples Statistics

\begin{tabular}{|cc|c|c|c|c|}
\hline & Mean & $\mathrm{N}$ & Std. Deviation & Std. Error Mean \\
\hline Pair 1 & pre_test & 73.74 & 105 & 4.564 & .445 \\
& post_test & 80.02 & 105 & 3.029 & .296 \\
\hline
\end{tabular}

Paired Samples Correlations

\begin{tabular}{|c|c|c|c|}
\hline & $\mathrm{N}$ & Correlation & Sig. \\
\hline Pair 1 pre_test \& post_test & 105 & .136 & .167 \\
\hline
\end{tabular}

Dengan menggunakan Paired Samples Tes dapat diketahui bahwa perbedaan skor antara skor pre tes dan post tes adalah -6,276 dimana rata-rata skor pretest adalah 73,42 dan rata-rata skor posttest adalah 80,02. Standar deviasi pre tes adalah 4,564 dan standar deviasi post tes 3,029. Nilai minimum pre tes adalah 53 dan nilai maksimum pre tes adalah 82 . Nilai minimum post tes adalah 75 dan nilai maksimum post tes 92 . Nilai t hitung didapat $-12,555$ dengan signifikansi $\mathrm{p}=0,000$ atau ( $\mathrm{p}<0,05)$, yang berarti $\mathrm{H} 0$ ditolak dan $\mathrm{H} 1$ diterima, sehingga dapat disimpulkan bahwa ada perbedaan rata-rata antara skor pre tes dan skor post tes pada uji tes mata pelajaran Produk Kreatif dan Kewirausahaan pada pelaksanaan uji coba luas (lapangan) dengan menggunakan Aplikasi Sakpore.

Selain uji coba luas yang dilaksanakan di SMK N 2 Pekalongan, peneliti juga melakukan uji coba luas tahap kedua, yang dilakukan pada guru Produk Kreatif dan Kewirausahaan yang tergabung pada MGMP Produk Kreatif dan Kewirausahaan Kota Pekalongan sejumlah 8 (delapan) guru. Uji coba ini dilakukan untuk memberikan tanggapan terhadap Aplikasi meliputi aspek manfaat, kelengkapan dan rekayasa. Pelaksanaan uji coba media ini dengan cara daring melakukan penilaian terhadap Aplikasi Sakpore. Hasil yang didapat pada pelaksanaan uji coba lapangan ini dalam bentuk tabel distribusi frekuensi sebagai berikut.

Tabel 16. Aspek Manfaat pada Uji Coba Luas MGMP

\begin{tabular}{ccccc}
\hline No & Interval & Frekuensi & Prosentase $(\%)$ & Kategori \\
\hline 1. & $4-8$ & 0 & 0 & Tidak Setuju \\
2. & $9-12$ & 0 & 0 & Kurang setuju \\
3. & $13-16$ & 4 & 28.6 & Setuju \\
4. & $17-20$ & 10 & 71.4 & Sangat Setuju \\
\hline & Total & 14 & 100.0 & \\
\hline
\end{tabular}


Dari tabel 16 Aspek Manfaat Aplikasi prosentase terbesar pada kategori sangat setuju. Deskripsi tentang aspek manfaat media diperoleh melalui prosedur frekuensi dalam program SPSS 16 yang dilakukan terhadap 14 guru. Hasil perhitungan diketahui bahwa nilai mean = 17,$2143 ;$ median $=17,0 ;$ standar devias $i=1,36880 ;$ variance $=1,874 ;$ range $=4 ;$ terendah $=$ 15 dan tertinggi $=19$.

Tabel 17. Aspek Kelengkapan pada Uji Coba Luas MGMP

\begin{tabular}{ccccc}
\hline No & Interval & Frekuensi & Prosentase (\%) & Kategori \\
\hline 1. & $4-8$ & 0 & 0 & Tidak Setuju \\
2. & $9-12$ & 0 & 0 & Kurang setuju \\
3. & $13-16$ & 4 & 28.6 & Setuju \\
4. & $17-20$ & 10 & 71.4 & Sangat Setuju \\
\hline & Total & 14 & 100.0 & \\
\hline
\end{tabular}

Dari tabel 17 Aspek kelengkapan Media Penilaian Aplikasi prosentase terbesar pada kategori sangat setuju. Deskripsi tentang aspek kelengkapan media diperoleh melalui prosedur frekuensi dalam program SPSS yang dilakukan terhadap 8 Guru. Hasil perhitungan diketahui bahwa nilai mean $=17,2143 ;$ median $=17,0 ;$ standar deviasi $=1,36880 ;$ variance $=1,874$; range $=4$; terendah $=15$ dan tertinggi $=19$.

Tabel 18. Aspek Rekayasa pada Uji Coba Luas MGMP

\begin{tabular}{ccccc}
\hline No & Interval & Frekuensi & Prosentase $(\%)$ & Kategori \\
\hline 1. & $4-8$ & 0 & 0 & Tidak Setuju \\
2. & $9-12$ & 0 & 0 & Kurang setuju \\
3. & $13-16$ & 4 & 28.6 & Setuju \\
4. & $17-20$ & 10 & 71.4 & Sangat Setuju \\
\hline & Total & 14 & 100.0 & \\
\hline
\end{tabular}

Dari tabel 18 Aspek Rekayasa Media Penilaian Aplikasi prosentase terbesar pada kategori sangat setuju. Deskripsi tentang aspek rekayasa media diperoleh melalui prosedur frekuensi dalam program SPSS yang dilakukan terhadap 8 guru. Hasil perhitungan diketahui bahwa nilai mean $=17,2143 ;$ median $=17,0 ;$ standar deviasi $=1,36880 ;$ variance $=1,874$; range $=4$; terendah $=15$ dan tertinggi $=19$.

\section{Pembahasan}

\section{Hasil Pengembangan Aplikasi Sakpore}

Dengan menerapkan model penelitian 4D yang terdiri dari 4 tahap yaitu Define, Design, Develop, dan Disseminate atau diadaptasikan menjadi model 4-P, yaitu pendefinisian, perancangan, pengembangan, dan penyebaran maka setelah dilakukan analisis kebutuhan maka media pembelajaran berbasis Android yang bisa digunakan untuk kegiatan pembelajaran dan sarana latihan mengerjakan soal-soal dibutuhkan oleh peserta didik dan guru.

Perencanaan dilakukan dengan kajian pustaka dimulai dengan perencanaan materi atau soal-soal yang akan digunakan terkait dengan kompetensi yang telah diajarkan guru, perencanaan desain dan dilanjutkan dengan pembuatan aplikasi menggunakan android studio. Tahap validasi oleh tim ahli yang terdiri dari ahli materi dan ahli media serta guru sebagai pengguna Aplikasi. Revisi dan perbaikan dilakukan berdasarkan saran dan masukkan perbaikan dari tim ahli dan pengguna. Setelah diperbaiki selanjutnya Aplikasi digunakan dalam uji coba terbatas dan ujicoba luas. Hasil tampilan Aplikasi saat dijalankan pada perangkat handphone sebagai berikut. 

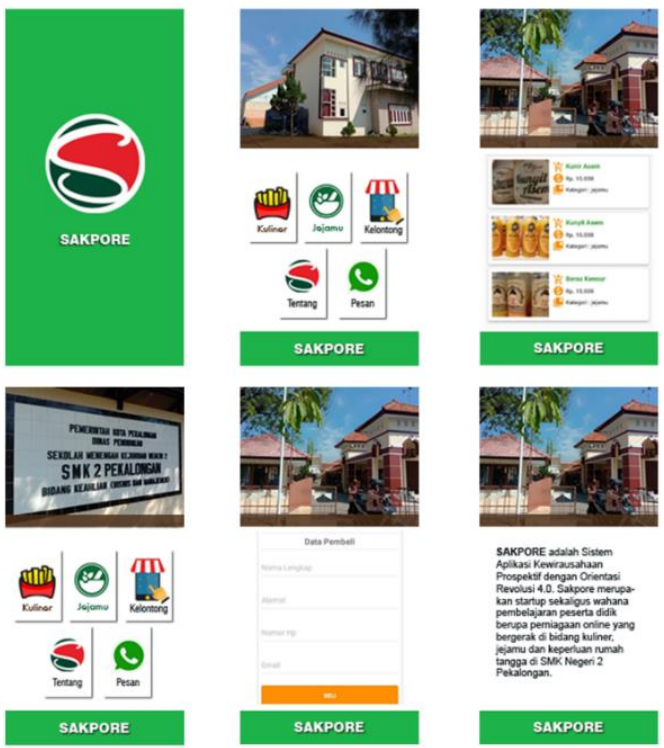

Gambar 3. Tampilan Aplikasi

\section{Kevalidan Aplikasi}

Kevalidan aplikasi media penilaian Aplikasi dinilai oleh ahli media dan ahli materi. Penilaian kevalidan aplikasi oleh ahli media dan ahli materi berdasarkan 3 aspek yaitu aspek materi, aspek media dan aspek rekayasa. Rerata skor total penilaian adalah rata-rata 54,00 (kategori sangat layak) masuk dalam skala skor 48,75 - 60 sehingga dapat dikatakan bahwa kevalidan aplikasi Sakpore berdasarkan penilaian oleh tim ahli dengan skor 54,00 termasuk dalam kategori sangat layak digunakan sebagai media pembelajaran.

Penilaian kevalidan aplikasi oleh pengguna yaitu guru. Berdasarkan 3 aspek yaitu aspek aspek materi, aspek media dan aspek rekayasa. Rerata skor total penilaian oleh pengguna adalah 46,00 (kategori layak). Kemudian skor tersebut dikonversikan dalam bentuk skor baku dengan rentang 0 sampai 100 . Nilai skor setelah dikonversikan adalah 80,53 sehingga dapat dikatakan bahwa kevalidan aplikasi media penilaian Aplikasi berdasarkan penilaian oleh pengguna dengan skor 80,53 termasuk dalam kategori layak digunakan sebagai media pembelajaran.

Penilaian produk dalam hal ini Aplikasi oleh peserta didik secara grafik ditampil sebagai berikut:

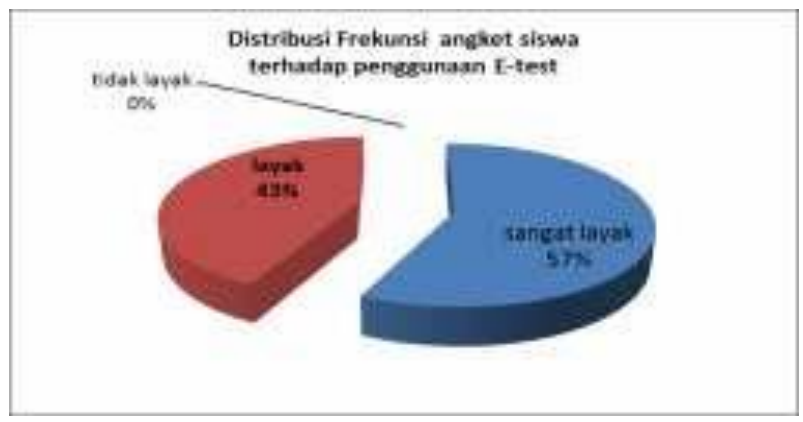

\section{Gambar 4. Diagram distribusi aplikasi oleh peserta didik}

Dari gambar 10 dapat diketahui bahwa 57\% peserta didik menyatakan bahwa aplikasi Sakpore dalam kategori "sangat layak" sebagai media pembelajaran. Sedangkan $43 \%$ peserta didik menyatakan aplikasi dalam kategori "layak" digunakan sebagai media pembelajaran. Sedangkan penilaian Aplikasi yang dilakukan Guru Produk Kreatif dan Kewirausahaan pada MGMP Guru Produk Kreatif dan Kewirausahaan, didapatkan masukan 1) Materi dikembangkan dengan simulasi dan perhitungan biaya produksi serta nilai jual; 2) latihan 
dikembangkan dengan konsep bertingkat ( level satu lulus baru level 2 aktif dan seterusnya); dan 3) soal latihan di sesuaikan dengan KI KD kurikulum terbaru.

\section{Keefektifan Aplikasi}

Keefektifan Aplikasi ditentukan dengan cara melihat pencapaian ketuntasan hasil belajar aspek pengetahuan dan keterampilan peserta didik dengan melakukan ujian menggunakan Aplikasi Sakpore. Keefektifan pemakaian Aplikasi diuji coba dengan mengadakan pre test dan post test. Pretes dilakukan diawal jam pertemuan, treatment diberikan dengan memberi kesempatan peserta didik melakukan literasi dengan membaca materi Produk Kreatif dan Kewirausahaan dalam aplikasi, serta mengerjakan latihan soal pada tombol latihan. Pada akhir jam pelajaran dilaksanakan posttest menggunakan Aplikasi versi Ujian. Berikut adalah rata-rata hasil belajar peserta didik untuk setiap jurusan baik pada uji terbatas maupun uji luas.

Tabel 19. Rata-rata hasil pretest dan posttest

\begin{tabular}{|c|l|c|c|c|c|}
\hline No & \multicolumn{1}{|c|}{ Uji } & Kelas & Pre-Test & Post-Test & Keterangan \\
\hline 1 & Uji terbatas & XI PSPT & 73.99 & 80.03 & Meningkat \\
\hline 2 & Uji Luas & X PSPT & 73.47 & 80.55 & Meningkat \\
& & XI PSPT & 72.49 & 81.38 & Meningkat \\
& & XI BDPM & 73.54 & 80.71 & Meningkat \\
\hline
\end{tabular}

Pembelajaran dilakukan pada kelas XI PSPT pada uji terbatas dan 3 (tiga) kelas jurusan X PSPT, XI PSPT dan XI BDPM. pada uji setiap kompetensi dasar di uji dengan pre test dan post test. Hasil belajar yang didapat untuk semua kelas pada uji terbatas maupun uji luas pada materi Produk Kreatif dan Kewirausahaan meningkat. Rata-rata hasil belajar uji terbatas kelas X PSPT posttest dari sebesar 80,03 lebih besar dari hasil pre test sebesar 73,99 maka rata-rata hasil belajar dari materi Produk Kreatif dan Kewirausahaan adalah meningkat. Rata-rata hasil belajar uji luas pada kelas X PSPT posttest sebesar 80,55 lebih besar dari hasil pretest sebesar 72,49 maka rata-rata hasil belajar pada materi Produk Kreatif dan Kewirausahaan adalah meningkat. Rata-rata hasil belajar kelas XI PSPT dari hasil posttest sebesar 81,38 lebih besar dari hasil pretest sebesar 72,49 maka rata-rata hasil belajar pada materi Produk Kreatif dan Kewirausahaan adalah meningkat. Rata-rata hasil belajar dari kelas XI BDPM hasil posttest sebesar 80,71 lebih besar dari hasil pre test sebesar 73,54 maka rata-rata hasil belajar pada materi Produk Kreatif dan Kewirausahaan adalah meningkat. Dilihat dari rata-rata hasil belajar semua kelas baik pada uji terbatas maupun uji luas pada materi Produk Kreatif dan Kewirausahaan, dengan Aplikasi Sakpore dapat meningkatkan hasil belajar sekaligus minat peserta didik pada aspek pengetahuan dan keterampilan. Evaluasi pembelajaran menggunakan Aplikasi ini selain bisa meningkatkan hasil belajar juga bisa menghemat kertas.

Aplikasi ini disiapkan dalam 2 versi oleh guru, versi latihan dan versi ujian. Versi latihan diberikan pada peserta didik dalam format.apk yang pendistribusiannya atau penyebaranya bisa secara on-line maupun offline bahkan dapat di download langsung di Playstore untuk android. Dengan versi latihan ini peserta didik bisa berlatih mengerjakan soal-soal secara individu maupun kelompok. Aplikasi Versi ulangan hanya boleh dipakai saat guru melaksanakan evaluasi yang sesungguhnya. Perhitungan statistik dengan SPSS 16 menggunakan Paired Samples Tes Nilai $\mathbf{t}$ hitung didapat $-8,252$ dengan signifikansi $\mathrm{p}=0,000$ atau $(\mathrm{p}<0,05)$, yang berarti $\mathrm{H} 0$ ditolak dan $\mathrm{H} 1$ diterima, sehingga dapat disimpulkan bahwa ada perbedaan rata-rata antara skor pretes dan skor posttes pada mata pelajaran Produk Kreatif dan Kewirausahaan, sehingga dapat bahwa Aplikasi ini merupakan media penilaian yang efektif untuk digunakan sebagai salah satu media pembelajaran. 


\section{KESIMPULAN}

Kondisi awal pembelajaran Produk Kreatif dan Kewirausahaan sebelum pemanfaatan aplikasi sakpore adalah guru masih banyak menggunakan kertas, guru melakukan presentasi dengan powerpoint dan beberapa sudah menggunakan e-Modul.

Pengembangan Sistem Aplikasi Sakpore Desain media penilaian Aplikasi meliputi tampilan opening, menu utama, petunjuk penggunaan, latihan soal dan hasil latihan berdasarkan rangking. Kevalidan Aplikasi dilakukan oleh ahli media, ahli materi dan pengguna yaitu guru dan peserta didik, diperoleh skor rata-rata 54,00 dan masuk dalam kategori sangat layak.

Kelayakan Sistem Aplikasi Kewirausahaan Prospektif dengan Orientasi Revolusi 4.0 (SAKPORE) dilakukan dengan membandingkan hasil belajar pretest dan posttest aspek pengetahuan dan keterampilan pada mata pelajaran Produk Kreatif dan Kewirausahaan. Hasil rata-rata pretest dan posttest mengalami peningkatan baik pada uji terbatas dan uji luas, yaitu dari rata-rata 73.37 menjadi rata-rata 80.68. Hasil ini sekaligus meningkatkan minat peserta didik menjadi seorang wirausaha.

\section{DAFTAR PUSTAKA}

Barba-Sánchez, V. (2018). Entrepreneurial intention among engineering students: The role of entrepreneurship education. European Research on Management and Business Economics.

Jaedun, A. (2015). Pengembangan Model Pembelajaran Produktif Bermuatan Kewirausahaan Bagi Peserta didik SMK. Jurnal Kewirausahaan.

Kompas. (2019). Digitalisasi Masuk di Pemelajaran SMK. Selasa, 8 Oktober 2019.

Perdana. (2013). Pengembangan Buku Digital (BUDIN) Berbasis Adobe Creative Suite pada Materi Genetika di SMK. Universitas Negeri Semarang.

Pradani. (2017). Building Students Entrepreneurship Skills Through the Production and Marketing Practices. Maulana Malik Ibrahim State Islamic University.

Risnawati. (2015). Pengembangan Media Pembelajaran Akuntansi Berbentuk Modul Pembelajaran Digital untuk Peserta didik SMK Negeri 1 Bantul. Universitas Negeri Yogyakarta.

Savitri, A. (2019). Revolusi Industri 4.0 Mengubah Tantangan Menjadi Peluang di Era Disrupsi 4.0 (T. Afkar, Ed.). Yogyakarta: Penerbit Genesis.

Silvius, A. J. G. (2015). Exploring Functionality of Mobile Applications for Project Management. Procedia Computer Science.

Sussi Widiastuti. (2018). Implementasi Model Pembelajaran Tefapreneur untuk Membangun Minat dan Keberanian peserta didik Berwirausaha. Jurnal Guru Dikmen Dan Diksus.

Wiklund, J. (2019). Entrepreneurship and well-being: Past, present, and future. Journal of Business Venturing. 